\title{
The Aberrant Expression of Lewis a Antigen in Intestinal Metaplastic Cells of Gastric Mucosa is Caused by Augmentation of Lewis Enzyme Expression
}

\author{
胃に生じる腸上皮化生に出現してくるルイスa抗原はルイス酵素の \\ 発現上昇によるものである \\ Ikehara, Yuzuru \\ Division of Pathology I, Aichi Cancer Center Research Institute, Chikusa-ku, Nagoya, Aichi, Japan \\ FAX: 81-52-762-2974, E-mail: yikehara@aichi-cc.pref.aichi.jp
}

Key Words : intestinal metaplasia, Lewis a antigen, Lewis enzyme

Intestinal metaplasia, which replaces proper gastric mucosa with small intestinal-type cells, appears in gastric mucosa in association with aging, mucosal disorders and gastric neoplasia. There are similarities to gastric cancers from several points of view and the condition is often observed together with stomach tumors in surgically resected specimens. Therefore, metaplasia has been thought to be associated with carcinogenesis of the gastric mucosa. In addition, aberrant expression of carbohydrate antigens such as Lewis $\mathrm{A}\left(\mathrm{Le}^{\mathrm{a}}\right)$ in secretors normally typified by Lewis B (Le $)$ (Fig. 1), and of Sialyl Tn, which is a feature of gastric cancer, have been thought to point to
腸上皮化生 (Intestinal metaplasia)とは、胃固有粘膜が小腸型 上皮によっておき変えられる現象のことある。そしてその出現 は、加齢や胃粘膜障害および腫瘍が関係している。腸上皮化生 はいくつかの点で胃癌と類似性がある他、外科手術によって切 除された検体(切除胃)では、まま腫瘍と共存しているのをみるこ とがある。それゆえ、腸上皮化生は胃粘膜の発癌に何らかの関 係のある病変であると考えられてきた。それに加えて、通常は ルイスb抗原 (Leb抗原)を発現するはずの分泌型(Secretor)でルイス a抗原が出現したり(図1)、シアリル Tn (STn)抗原が出現してくる といったような、化生性変化に伴う異常糖鎖抗原の出現は胃癌

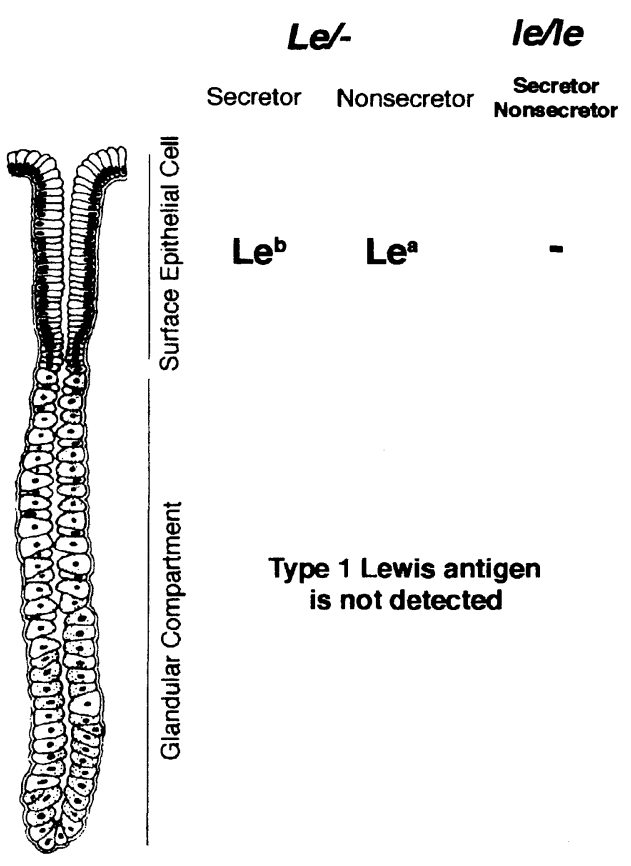

Fig. 1.

Glycoconjugate J. 1998 Vol. 15, No. 8, pp. 799-807. 


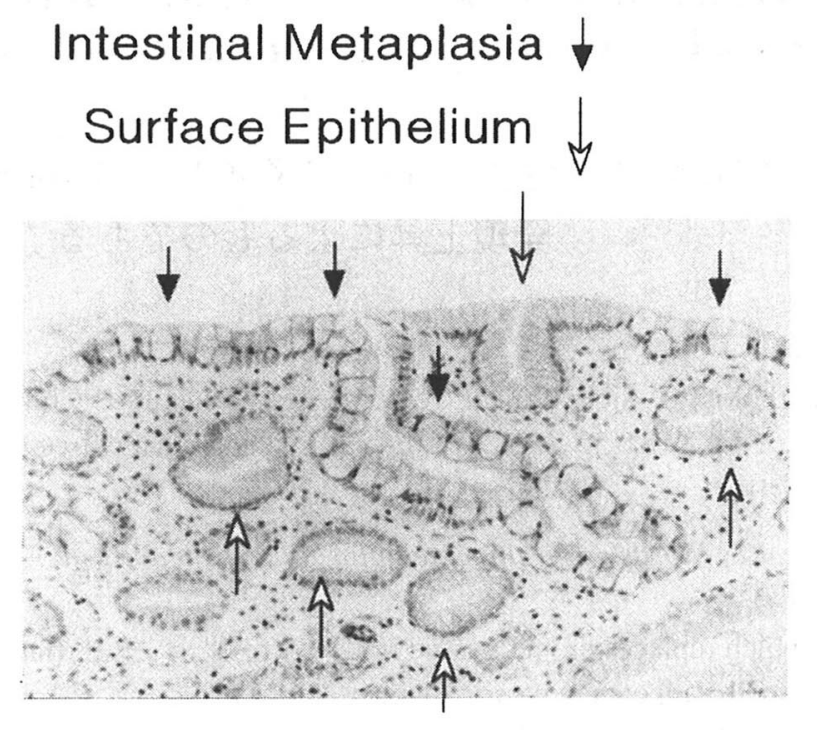

important implications for carcinogenesis. However, the mechanisms underlying such expression are unknown. The present experiment was conducted for the purpose of clarifying enzymatic alterations related to the Le antigen appearance in intestinal metaplasia in Secretors.

Gastric mucosa are covered with tubular glands which consist of surface epithelial cells and glandular components. Type1 Lewis antigens are normally detected only on surface epithelial cells, according to the Lewis blood type. (Fig.1) In this study, we demonstrated for the first time that the Lewis enzyme well co-localizes with Le ${ }^{\mathrm{a}}$ antigen, indicating an involvement in its synthesis in the gastric mucosa.

More intensive immunohistochemical staining of the enzyme was found in the intestinal metaplastic cells than in sur-
Fig. 2.

と共通の事象であると言うこともあって、癌発生に重要な意味 あいを持つのではないかと考えられてきた。しかしながら、こ のような異常発現を説明しうる機構は未だ明らかにされていな い。この研究は分泌型(Secretor)でルイスa抗原 (Lea抗原)が出現し てくることに関与する酵素学的变化を明らかにすることを目的 とした。

胃粘膜は表層を覆う細胞(表層上皮細胞)と腺細胞部分からな る管状腺管が被覆している。一型ルイス抗原は通常、表層上皮 細胞のみにルイス血液型に一致してみられる。(図 1) この研究 では、ルイス酵素が表層上皮細胞でLe抗原と局在を同じくして いることを明らかにし、これが胃粘膜でのLea抗原合成に関与す るであろうことをはじめて明らかにした。

これを元にして、免疫組織化学染色で、図2に示すように分 泌型、非分泌型によらず、固有胃粘膜の表層上皮とくらべて腸

\section{Synthetic pathway of type 1 Lewis histo-blood antigens}

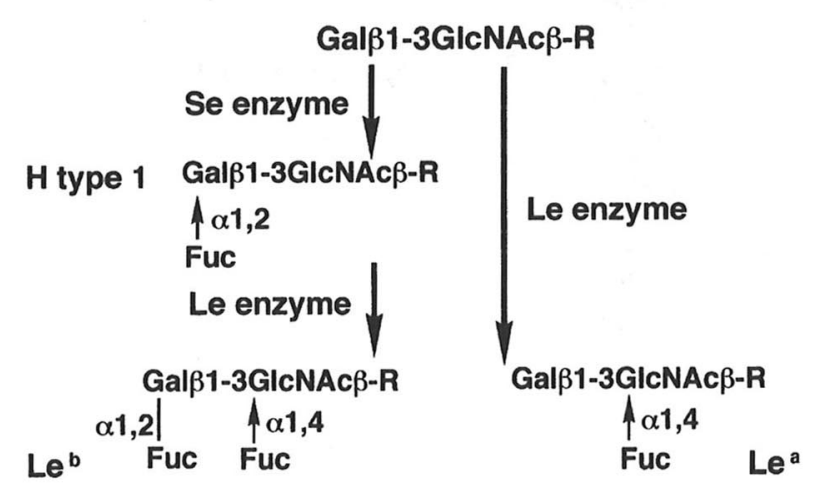

Fig. 3. 
face epithelial cells (Fig. 2), regardless of the Secretor status. The amounts of mRNA transcripts for the Lewis gene also correlated positively with the degree of metaplasia. This augmentation of the Lewis enzyme in metaplastic tissues was also confirmed by Western blotting analysis using a specific antibody against the Lewis enzyme.

We conclude that intestinal metaplastic change of gastric mucosa is usually accompanied by a marked augmentation of the Lewis enzyme expression, which results in enhanced production of Le $\mathrm{e}^{\mathrm{l}}$ antigen, particularly in Secretors. (Fig. 3)

This is the first indication of an enzymatic mechanism of aberrant Le $\mathrm{L}^{\mathrm{a}}$ antigen expression in gastric mucosa.
上皮化生性細胞にルイス酵素が強く染め出されることを見い出し た。この所見は、ルイス酵素遺伝子のmRNAが腸上皮化生の程度 と正の相関を示して増加していたこと、そしてルイス酵素に対す る特異抗体を用いたWestern Blottinによって示される酵素タンパ ク量の増加からも確認できる事象であった。

ゆえにわれわれは、胃粘膜の腸上皮化生性変化にともなった ルイス酵素の発現上昇が、分泌型でのLea抗原の合成艺進をもた らしているのだと結論付けた。(図 3)

このことは、胃粘膜の腸上皮化生でLe抗原が異常に出現し てくる酵素学的な機構をはじめて示すものである。

\section{Profile of the Author}

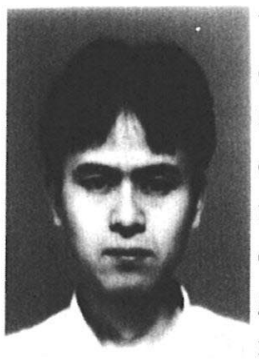

\section{Yuzuru lkehara}

Graduated from Shiga University of Medical Science in 1994 and passed the Examination of National Board. Obtained a Ph.D degree from Shiga Univ. of Med. Sci., in 1998 based on "The aberrant expression of Lewis a antigen in intestinal metaplastic cells of gastric mucosa is caused by augmentation of Lewis enzyme expression." (Prof. Hisashi Narimatsu Division of Cell Biol. Inst. of Life Sci., Soka Univ.) He started his professional career as Researcher of Laboratory of Pathology, Aichi Cancer Center Research Institute. His research interests are carbohydrate antigen variation in gastric epithelial cell differentiation and metaplastic change. Recent research of this young pathologist focuses on Sialyl-Tn antigen which upregulate in Goblet cells of intestinal metaplasia as well as Lewis enzyme. Future efforts shall focus on the biological role of STn antigen and the Goblet cell differentiation . 